удК 339.138

\title{
КОНЦЕПТУАЛЬНІ ПІДХОДИ ДО СТІЙКОГО РОЗВИТКУ ПРОМИСЛОВИХ ПІДПРИЕМСТВ І ФОРМУВАННЯ МАРКЕТИНГУ СТІЙКОСТІ
}

\author{
CONCEPTUAL APPROACHES TO SUSTAINABLE \\ DEVELOPMENT OF INDUSTRIAL ENTERPRISES \\ AND FORMATION OF SUSTAINABILITY MARKETING
}

\author{
Могилевська Ольга Юріївна \\ доктор економічних наук, доцент, \\ Київський міжнародний університет \\ ORCID: https://orcid.org/0000-0001-8482-7950
}

\author{
Mohylevska Olga \\ Kyiv International University
}

\begin{abstract}
У статті розглянуто стратегічні аспекти ведення сучасного промислового бізнесу. Досліджено еволюцію розвитку теорії маркетингу у процесі трансформаційних змін економічних систем. Розкрито особливості застосування маркетингу на промисловому ринку. Визначено сучасну парадигму маркетингової системи. Окреслено концептуальні підходи до стійкого розвитку промислових підприємств і фрормування маркетингу стійкості. Визначено, що маркетинг є системним утворенням, видом підприємницької діяльності, фрункцією управління, соціальним процесом, науковою дисципліною, фрілософією бізнесу; охоплює всі сфери людської діяльності; здійснюється у сорері обміну з метою забезпечення потреб споживачів і, опосередковано, досягнення ефективності діяльності.
\end{abstract}

Ключові слова: промислове підприємство, маркетингова система, конкурентоспроможність, ефективність, інновації, цифровізація, ключові компетенції, державне-приватне партнерство, стійкий розвиток.

В статье рассмотрены стратегические аспекты ведения современного промышленного бизнеса. Исследована эволюция развития теории маркетинга в процессе трансформационных изменений экономических систем. Раскрыты особенности применения маркетинга на промышленном рынке. Определена современная парадигма маркетинговой системы. Очерчены концептуальные подходы к устойчивому развитию промышленных предприятий и формированию маркетинга стойкости. Определенно, что маркетинг является системным образованием, видом предпринимательской деятельности, функцией управления, социальным процессом, научной дисциплиной, философией бизнеса; охватывает все сферы человеческой деятельности; осуществляется в сорере обмена с целью обеспечения потребностей потребителей и, опосредствовано, достижения эффрективности деятельности.

Ключевые слова: промышленное предприятие, маркетинговая система, конкурентоспособность, эффрективность, инновации, цифровизация, ключевые компетенции, государственно-частное партнерство, устойчивое развитие.

The article deals with the strategic aspects of conduct the modern industrial business. The evolution of development of marketing theory in the process of transformation changes of the economic systems is investigated. The features of application the marketing at the industrial market are exposed. The modern paradigm of the marketing system is certain. Conceptual approaches to sustainable development of industrial enterprises and forming the sustainable marketing are outlined. Certainly, that marketing is system formation; the type of entrepreneurial activity, a management function, a social process, scientific discipline, business philosophy; embraces all spheres of human activity; comes true in the field of exchange with the aim of providing of necessities of consumers and, mediated, achievement of activity efficiency. The concept of «sustainability of the marketing system» was introduced, which is proposed to be interpreted as the ability to form, to develop and long time to support the competitive edges of industrial business, providing the proper level of it's capitalization in the conditions of dynamic development of market environment and despite influence of risk and vagueness of marketing environment factors, at what it is suggested to take into account such types of firmness of the sustainability of the marketing system, as marketing, productive, administrative, financial firmness, investment-innovative, social, ecological, partner, informative. Under the «partner 
marketing of industrial enterprise» is suggested to understand the forming of partner relations in the process of collaboration with other subjects of market on mutually beneficial basis and trust with the aim of increase of efficiency of productive and market activity of enterprise, receipt the competitive edges, sustainable development on a long-term prospect due to access to innovative technologies and creation of unique consumer value for maximal satisfaction of market demand in the industrial products on all levels of marketing environment. In of turn, «sustainable marketing of industrial enterprises», is suggested to understand - as strategic conception of business that is base on holistic conception of marketing, first of all on the partner marketing, innovative marketing, social-ethic marketing, ecological marketing, marketing 4.0, stakeholders marketing, that is oriented to providing of sustainable development of industrial enterprises - high competition position at the market, capitalizations of brand on condition of innovative goods production; achievement of maximal satisfaction of all stakeholders and society for due to the social responsibility in the partner relations system, implementation of scientific and technical achievements and introduction of modern technologies to the chainlet of consumer value creation; «public-private partnership at the industrial market», is as an institute of mutually beneficial partner relations of the state and sole proprietors of industry, on the base of that symbiosis and association of resources, experience and knowledge of both parties sent to the decision of publicly-meaningful social and administrative tasks on principles of equality and freedom on condition of satisfaction of all concerned parties are formed. It will assist deepening to catigorical apparatus of economic theory in terms of marketing and marketing activity.

Keywords: industrial enterprise, marketing system, competitiveness, efficiency, innovation, digitalization, core competencies, public-private partnership, sustainable development.

Постановка проблеми. Досвід провідних країн світу та наслідки структурної і системної перебудови більшості сегментів національного господарства переконливо свідчать, що реальні зрушення в напрямі фрормування передумов стійкого розвитку як держави загалом, так і окремих регіонів, галузей досягаються за рахунок активізації економічної діяльності суб'єктів господарювання. Особлива роль у цьому процесі відводиться підприємствам промислового комплексу. Сучасні ринкові умови розвитку вітчизняної економіки характеризуються загостренням конкурентної боротьби між виробниками. Відповідно, за таких умов, роль маркетингу значно зростає в якості однієї із стратегічних систем підприємства, яка забезпечує зв'язок із зовнішнім середовищем, 3 огляду на що виникає необхідність у розробці ефективної маркетингової системи для забезпечення стійкого розвитку промислових підприємств 3 метою безперервного інноваційного розвитку технологічних та управлінських процесів, фрормування конкурентоспроможного виробництва, створення унікальної споживчої цінності на ринку В2В з урахуванням соціальної та екологічної складових.

Аналіз останніх досліджень і публікацій. Дослідження маркетингової діяльності на промислових підприємствах здійснювали такі вчені, як: І. Акімова, М. Долинська, Р. Фатхутдинов, Є. Крикавський, Л. Романова, О. Тєлєтов, Ф. Уебстер, Г. Хардінг, Н. Чухрай, О. Юлдашєва. Різні аспекти стійкого розвитку промислових підприємств досліджувалися у працях таких вчених, як: І. Акулова, Я. Бош, Г. Багієв, О. Дуброва, Ф. Котлер, О. Слободчикова, О. Юлдашева, Дж. Вебер, Е. Лоуренс та багато інших.
Формулювання цілей статті (постановка завдання). Слід визнати, що, незважаючи на підвищену увагу з боку українських і зарубіжних дослідників до маркетингової діяльності у промисловій сорері, проблематика стійкого розвитку промислових підприємств $€$ менш вивченою, ніж загальний їі напрямок, Тому ряд питань потребують подальшого вивчення. Метою даного дослідження $є$ обґрунтування теоретичних та практичних засад срормування маркетингової системи в забезпеченні стійкого розвитку промислових підприємств.

Виклад основного матеріалу дослідження. Економічні реформи, проведені в Україні, створюють певну основу для розвитку промислових підприємств країни на основі фрормування нових внутрішніх економічних відносин, заснованих на принципах маркетингу. Досвід низки зарубіжних компаній показує, що одним з перспективних підходів з забезпечення стійкості підприємства $€$ формування і розвиток маркетингової системи підприємства, яка зміцнюється за рахунок створення сприятливого оточення з дистриб'юторів, постачальників, споживачів і інших учасників бізнесу. В якості головного важеля підтримки даної системи виступають інновації, привабливі для клієнтів і партнерів. Основою маркетингової стратегії стають тісні виробничі зв'язки 3 партнерами, полегшення доступу до ресурсів всіх видів, визначення напрямків розвитку та фрінансування бізнесу. Для успішного фрункціонування маркетингової системи дуже важливий маркетинговий організаційний підхід. Якщо окремі сегменти даної системи підпорядкувати певним фрункціям або бізнес-групам, то ці сегменти швидше будуть відображати інтереси окремих власників бізнесу, ніж служити потре- 
бам клієнтів. Коли ж все елементи бізнессистеми об'єднані в одному маркетинговому просторі, з'являється можливість ефрективно відповідати на запити клієнтів, мобілізувавши для цього необхідні ресурси.

Найбільш важливим є те, що в центрі даної системи знаходиться клієнт. Сприйняття клієнтом всієї діяльності підприємства створює імідж торгових марок, визначаючи в кінцевому підсумку його успіх в бізнесі. На наш погляд, маркетингова система націлена на задоволення потреб клієнта, що дозволяє підприємству безперервно покращувати свою здатність завойовувати і утримувати споживачів. У зв'язку з цим управління взаємовідносинами 3 клієнтами стає ядром успішної маркетингової стратегії бізнесу. Використовуючи своє знання клієнтів, підприємства можуть краще виявляти нові можливості продажів і встановлювати їх пріоритети, використовувати нові способи позиціонування на ринку, прискорювати розробку інноваційних продуктів і послуг, а також зміцнювати взаємини зі споживачами та бізнес-партнерами. Завдяки підвищенню лояльності покупців підприємство може розраховувати на збільшення доходів. Швидка адаптація бізнес-процесів до мінливих ринкових умов і потреб клієнтів створює додаткові конкурентні переваги.

Вигоди від залученості партнерів у маркетингову систему бізнесу отримують як структурні підрозділи підприємства, орієнтовані на взаємодію 3 клієнтами, так і допоміжні. Маркетингова система забезпечує злагоджену роботу не тільки відділів маркетингу, продажів і обслуговування, а й діяльність в галузі фрінансів, управління персоналом, розробки нових продуктів і управління логістикою, у тому числі управління запасами, підбір постачальників, обробка замовлень, доставка товару. Кожне підприємство, вибудовуючи свою маркетингову систему, має приділяти особливу увагу не тільки вивченню і підтримці зв'язків зі своїми клієнтами, а й розвитку партнерських відносин. Управляючи всім циклом партнерських відносин, підприємство отримує можливість прикріпити існуючих і потенційних клієнтів до потрібних торгових партнерів відповідно до їхнього профрілю. При цьому взаємовигідному підході організація, з одного боку, отримує доступ до даних про роботу партнера, його потенційних клієнтів, фрактичних обставин і подальші дії, а з іншого боку, надає своїм партнерам знання, інструменти та консультації, необхідні для більш ефективних продажів і обслуговування клієнтів.
Для забезпечення конкурентних переваг в умовах мережевої системи, використання цифрових технологій, на наш погляд, дасть можливість швидко впроваджувати нові моделі ведення бізнесу, що виходять за рамки традиційних ланцюжків створення споживчої цінності і охоплювати цілі мережі, орієнтовані на клієнтів і попит. Підприємствам необхідно удосконалювати операційні процеси відносин 3 клієнтами і партнерами. Це може бути збільшення продуктивності і есрективності шляхом раціоналізації наскрізних бізнес-процесів, зниження вартості запасів і поліпшення процесів від прийняття замовлення до надходження платежів. Більш надійні бізнес-процеси допоможуть підвищити рівень обслуговування і скоротити витрати.

3 наукової точки зору мережева система являє собою замкнуту систему, яка характеризується певною стійкістю розвитку, вимагаючи мінімального впливу ззовні. Під мережевою системою слід мати на увазі, у першу чергу, партнерські і клієнтські мережі. Спільність клієнтів, партнерів і підприємства, їх взаємодію на державно-приватному рівні як раз і фрормує маркетингова система промислового підприємства. Основним завданням маркетингової системи є інвестиції у розвиток: зростання бізнесу, капіталізацію власного бренду і отримання більшого прибутку завдяки продажу більшого обсягу продукції та послуг за допомогою партнерів. Таким чином, синергетична маркетингова система включає в себе співробітників, клієнтів і партнерів, постійно створюючи й надаючи споживчі цінності, стимулюючи інновації. Підприємства, здатні побудувати настільки гнучку систему, яка зможе швидко реагувати на зміну потреб клієнтів і умов ведення бізнесу, отримати значні конкурентні переваги, підтримуючи і розкриваючи свій інноваційний потенціал [1].

Сьогодні ні у кого не викликає сумніву той фракт, що безперервне впровадження нововведень - єдиний спосіб підтримки високих темпів розвитку організації і рівня доходності. Інноваційний шлях розвитку економіки обумовлений наступними головними причинами: виникнення нових потреб у зв'язку зі змінами довкілля, посилюванням глобальних проблем; переходом до стратегії «стійкого розвитку». Інноваційна діяльність промислового підприємства стає ядром конкурентної стратегії. Нові знання дозволяють не лише удосконалювати продукти і послуги, але і знижувати собівартість виробів і покращувати їх якість. Маркетингові інновації сприяють зрос- 
танню промислових підприємств і реалізації їх потенціалу. Стійкий розвиток (sustainable development) означає безперервно підтримуваний розвиток, тобто такий, який не суперечить подальшому існуванню людства. Основна ідея концепції стійкого розвитку полягає у формулюванні умов і стратегії, здатних забезпечити рішення все більш очевидних глобальних проблем екологічної і промислової політики [2]. Економічне зростання і методи його досягнення позначаються на екології, морально-етичному вихованні людства, на рівні життя, темпах науково-технічного розвитку, концентрації капіталу і інших чинниках глобального середовища. 3 точки зору синергетики сьогоднішній стан світової системи характеризується хаотичністю еволюційного розвитку складних систем, порушується загальний темп зростання складної структури, необхідний для її стійкого розвитку. Стратегія стійкого розвитку - інноваційний підхід до подальшого розвитку цивілізації і вимагає розробки інноваційних програм в усіх copepax, у тому числі у промисловій.

Причому, одне з основних завдань маркетингу нині - це фрормування попиту на інновації, що покращують якість життя, економію ресурсів, сприяючі фрормуванню нового суспільства, підвищенню інтелекту. Аналіз тенденцій і перспектив розвитку вітчизняної промисловості, виявив наявність комплексу проблем, що ведуть до зниження ефективності і стійкості фрункціонування промислових підприємств. Основними з них є: низький рівень технічного розвитку, інфрормаційного забезпечення і конкурентоспроможності продукції, низька інноваційна і інвестиційна активність, недостатня забезпеченість кваліфрікованими кадрами, недосконалість соціальної політики і так далі. Перераховані та багато інших проблем у фрункціонуванні промислових підприємств пов'язані, у першу чергу, з неефективною маркетинговою діяльністю, що $€$ своєрідним «гальмом» їх розвитку. Сучасні підходи пропонують створення не лише окремих елементів маркетингової діяльності, а фрормування єдиної системи, де усі елементи взаємозв'язані.

Якщо раніше вимоги ринку формувалися потребами споживачів, то надалі стали враховувати інтереси суспільства. Зараз у зв'язку 3 погіршенням екології з'явився екологічний маркетинг. Нині все більший вплив на світову спільноту мають глобальні проблеми людства. 3'явилася нова стратегія стійкого розвитку. Нові підходи вимагають впровадження нової маркетингової концепції гармонізації розвитку - маркетингу стійкості - нової орілософрії бізнесу. Цей підхід включає використання принципів достатності, раціональності, блага, творчості і враховує не лише інтереси людини, але і усього людства і інтереси майбутніх поколінь. Для переходу на нову концепцію розвитку необхідно формувати новий світогляд, заснований на новій парадигмі. Завдання сучасного маркетингу - фрормування попиту на інновації, використання яких сприятиме розвитку нових взаємовідносин, нової системи розвитку, що приносить благо для усього суспільства. Для цього необхідно застосовувати сучасні ефективні інструменти маркетингу, пов'язані в єдину маркетингову систему.

Найбільш актуальним завданням для фрормування і вдосконалення діяльності будьякого підприємства $€$ пошук чинників, які можуть створити стратегічний фрундамент для його стійкого розвитку в умовах нестабільності зовнішнього середовища. Такий стратегічний фрундамент грунтується на ухваленні управлінських рішень, які спрямовані на створення позитивного іміджу підприємства, зростання конкурентоспроможності продукції, формування лояльності споживачів, нарощування інноваційного потенціалу та інвестиційної привабливості підприємства. Базисом успішного розвитку підприємства в стратегічній перспективі $є$ його маркетингова стійкість. Сутності маркетингової стійкості підприємства присвячені роботи низки сучасних дослідників, які розглядають це поняття з різних точок зору, враховуючи ринкову кон'юнктуру, що постійно змінюється, інноваційність маркетингового інструментарію, досить високий рівень залежності сучасного підприємства від зміни макроекономічних і соціально-політичних процесів у світі.

Маркетингова стійкість - це здатність підприємства утримувати міцну конкурентоздатну позицію на ринку, досягати запланованого обсягу продажів, адаптуватися до змін ринкової кон'юнктури і відповідати справжнім і майбутнім запитам споживачів у співвідношенні якість/ціна [3]. Маркетингова стійкість підприємства припускає максимально можливе використання ринкових умов, усіх комерційних чинників для досягнення основної мети - отримання прибутку та капіталізації власного бренду. Ця орієнтація стратегії стійкості визначає сукупність тактичних прийомів виходу на ринок через розробку системи маркетингових заходів. Маркетингова стійкість $€$ складовою ефрективного менедж- 
менту, важливим важелем ухвалення стратегічних управлінських рішень, а маркетинг $€$ засобом досягнення стратегічних цілей стійкого розвитку. Аналіз маркетингової стійкості промислового підприємства дозволяє оцінити ефективність маркетингової діяльності, посилити конкурентну позицію підприємства у ринковому середовищі.

Можна виділили наступні функціональні складові стратегічної маркетингової стійкості вітчизняного промислового підприємства:

- фрінансова стійкість - здатність підприємства працювати з високим рівнем рентабельності, підтримувати оптимальний рівень ліквідності та платоспроможності, можливість мати джерела забезпечення стабільного прогресивного розвитку;

- виробнича стійкість - здатність підприємства підтримувати виробничий потенціал на рівні, що дозволяє забезпечити беззбитковий обсяг виробництва та безперебійний процес виготовлення продукції;

- соціальна стійкість - здатність підприємства підтримувати низькій рівень плинності кадрів та високий мотиваційний потенціал;

- екологічна стійкість - взаємозв'язок екологічної безпеки підприємства, та мінімізації шкідливого впливу господарської діяльності на навколишнє середовище;

- управлінсько-організаційна стійкість здатність керівників підприємства підтримувати високий рівень організаційної роботи та управління на підприємстві [4].

Після офріційного проголошення Концепції стійкого розвитку на асамблеї ООН в 1991 р. френомени «маркетинг стійкості» і «стійке споживання» все більше захоплюють український промисловий ринок, стимулюючи дослідження поведінки споживачів і їх відношення до стійких цінностей $[4 ; 5]$. Проте, існуючі дослідження в цій сорері носять розрізнений характер, що ускладнює розробку загальних підходів і стратегії поведінки промислових компаній на нових ринках.

Термін «маркетинг стійкості» з'явився у 1995 році в роботі Дж. Шета і А. Парватияра і був визначений як «спосіб примирення економічних і екологічних чинників за рахунок інноваційних товарів і виробничих систем». Очевидно, що в цих інтерпретаціях маркетинг стійкості зводиться тільки до питань захисту екосистем. Проте, з позицій екологічного підходу, кращий товар - це відсутність товару, повне невтручання в екосистеми. Тому під терміном «маркетинг стійкості» пропонується розуміти концепцію, що з'явилася в результаті розвитку маркетингу, яка включає побудову і розвиток стійких стосунків з соціальним і природним довкіллям і створення нової споживчої цінності завдяки інтеграції екологічних технологій виробництва товарів і послуг, культури споживання і етично вивірених рішень щодо управління маркетинговою взаємодією [6]. На нашу думку, у цьому визначенні повною мірою відображені економічний і соціальний аспекти стійкого розвитку промислового підприємства. Маркетинг стійкості, як стверджують Франк-Мартін Белз и Кен Пітті в своїй статті «Стійкий маркетинг - інноваційна концепція маркетингу», $€$ розширенням концепції маркетингу стосунків в контексті усієї екосистеми [7]. Таким чином, маркетинг стійкості, на відміну від соціально-етичного, побудований на парадигмі маркетингу взаємодії, а не на трансакційній парадигмі, тобто припускає встановлення тісних і довгострокових взаємовідносин із споживачами для їх навчання та просування нових стійких моделей відповідального споживання.

Еволюція маркетингової теорії і практики, що відображає корінні зміни стосунків в інтерсрейсі «Бізнес - Суспільство - Природа», демонструє не лише трансорормацію маркетингових концепцій, але і поповнення маркетингової термінологічної парадигми [8]. Урядами розвинених країн і міжнародними організаціями активно просувається концепція стійкого розвитку (sustainable development), що вимагає необхідності оновлення фрілософії і інструментарія даної концепції для розвитку модернізованого капіталістичного суспільства, основним принципом якого $€$ - не створювати негативні соціальноекономічні і екологічні наслідки для нинішнього та майбутніх поколінь.

Р. Олдерсон розглядає маркетинг як організовану поведінкову систему і підкреслює послідовні перетворення, необхідні для відповідності великого асортименту вироблених товарів різноманітним вимогам окремих споживачів. Така поведінкова система організовується із-за очікуваних вигод. Очікування учасників взаємозв'язані, але не ідентичні, i учасники можуть конкурувати один 3 одним за контроль над системою або за збільшення своєї ролі в системі (у просуванні свого продукту на ринок). Таким чином, маркетингова система відображає цілі учасників та створюється і зберігається до тих пір, поки учасники задовольняють свої індивідуальні цілі.

До середини 1990-х рр., відбувався складний кумулятивний синтез різних, але ідеоло- 
гічно близьких, термінологій маркетингових концепцій. Серед тих, хто зробили внесок у теорію орормування концепції маркетингу стійкості можна відмітити:

- концепція громадського, або соціо-етичного маркетингу (societal marketing) [Feldman, 1971; Abratt, R. and Sacks, 1989];

- концепція соціального маркетингу (social marketing) [Kotler. and Zaltman, 1971; Andreasen, 1995];

- концепція зеленого маркетингу (green marketing) [Ottman, 1993];

- концепція екологічного маркетингу (ecological marketing) [Henion and Kinnear, 1975];

- концепція енвіронментального маркетингу (environmental marketing) [Peattie, 1995]);

- концепція маркетингу стосунків (relationship marketing) [Jackson, 1985; Gronroos, 1994; Gummesson, 1999];

- концепція маркетингу стейкхолдерів (stakeholder marketing) [Bhattacharya and Korschun, 2008];

- концепція маркетингу - «Маркетинг 3.0» [Kotler at al., 2010];

- концепція маркетингу - «Маркетинг 4.0» [Kotler at al., 2017].

У будь-якій компанії існує власна маркетингова діяльність: дослідження і фрормування ринку, розробка і реалізація маркетингової стратегії і тактики. Проте, особлива увага при реалізації концепції стійкого розвитку, на наш погляд, має бути звернена на логістичні потоки підприємства у ланцюжку створення споживчої цінності, по яких не лише здійснюється трансфрер матеріальних і нематеріальних (фрінансових, інформаційних потоків), але і визначається відповідність дій учасників (стейкхолдерів) логістичної мережі критеріям стійкого розвитку. Відомо, що загальна якість системи визначається за якістю того вузла мережі, який має найнижчу якість («принцип водопроводу»). Аналогічно, можна прийняти допущення, що становлення концепції стійкого розвитку у межах деякої мережі залежить від того, наскільки ця концепція прийнята «самими нестійкими» стейкхолдерами цієї мережі [9]. Таке положення представляється справедливим ще і тому, що у сучасному розумінні ланцюжок створення споживчої цінності на маркетингоорієнтованому підприємстві промислового ринку $є$ не тільки мережею стосунків В2В-одиниць, а складною мережевою системою 3 безліч стосунків зацікавлених сторін, яка потребує раціональної крос-срункціональної інтеграції. Оскільки завдання маркетингової діяльності щодо реалізації концепції стійкого розвитку у даній мережі потребує фрормування ефективної взаємодії усіх зацікавлених сторін, а також формування організаційної культури 3 поширенням ментальності стійкого розвитку серед стейкхолдерів, то особлива увага, на нашу думку, повинна бути приділена такій сучасній маркетинговій концепції як маркетинг стейкхолдерів.

Нарешті, внесок у модернізацію маркетингової концепції в контексті стійкого розвитку зробив також відомий американський економіст і маркетолог Філіп Котлер, який із співавторами спочатку ввів в науковий обіг «Маркетинг 3.0» [10], а потім і «Маркетинг 4.0». Отже, у Ф. Котлера [Marketing 3.0, 2010] поняття стійкості значною мірою виявляється схожим 3 поняттям корпоративної соціальної відповідальності і представлено на мікро- і мезорівнях маркетингового середовища. Проте, у попередній роботі «Principles of marketing» (2008) Ф. Котлер розкриває термін «Маркетинг» 3 точки зору SME-моделі (Sustainable Marketing Enterprise), що слід трактувати як комплексне «ведення справ 3 ринком» на відміну від традиційного розуміння поняття маркетингу як спеціалізованої бізнес-срункції. Sustainable Marketing Enterprise - це маркетингова модель, розроблена Хермаваном Картаджая перед обличчям усе більш складних і усеосяжних ринкових змін, може бути застосована будь-якою компанією, яка хоче, щоб ії маркетинг тривав і міг розвиватися відповідно до вимог часу. Система показників SME-моделі узгоджує інтереси різних сторін, залучених в діяльність компанії, а саме клієнтів, співробітників і інвесторів (включаючи власників).

Що стосується, «Маркетинг 4.0», то ця наукова праця зобов'язана своєю появою тотальній цифровізації бізнесу, що забезпечує, за словами авторів маркетингової концепції «Маркетинг 4.0»: «...поглиблення і розширення антропоцентричного маркетингу для охоплення усіх аспектів дії покупця» [11]. Ф. Котлер у даній роботі пропонує серйозну розмову про те, якими будуть покупці у світі, де стрімко зростає взаємопов'язаність спільнот та постають нові технології.

Енн Т. Лоуренс та Джеймс Вебер у своїй книзі «Business and Society: Stakeholders, Ethics, Public Polic» підкреслюють, що в сучасній економіці, де бізнес і уряд відіграють важливу роль, для стійкого розвитку бізнесу потрібно державне регулювання, а також нові моделі співпраці бізнес-співтовариства 3 дер- 
жавою [12]. Вони вважають, що бізнес несе не лише економічну, але і соціальну відповідальність перед суспільством. При цьому, етика і порядність украй важливі у системі відносин стейкхолдерів для самореалізації і успіху у бізнесі. Таким чином, відповідно до необхідності розробки оновленої маркетингової фрілософрії і технології стійкого розвитку капіталізму, що розуміє в суспільній свідомості, з середини 1990-х рр. стала набувати все більшої популярності концепція «маркетингу стійкості» (sustainable marketing). Петр Бош-Сийтсема і Ян Бош у своїй статті «Залучення користувачів в інноваційний процес у високотехнологічних галузях» пишуть: «Нові розробки в області технологій, соціальних мереж і нові способи тіснішої співпраці 3 клієнтами відкрили для фрірм нові можливості отримання інорормації від користувачів упродовж усього інноваційного процесу» [13]. Це аналогічно концепції маркетингу корпоративної соціальної відповідальності бізнесу, яка представлена на макро- і метарівні (на національному, регіональному і глобальному рівнях) маркетингового середовища.

В процесі нашого дослідження ми прийшли до висновку, що маркетинг стійкості для підприємств промисловості можна визначити як стратегічну концепцію бізнесу, яка грунтується на холістичній концепції маркетингу, насамперед на партнерському маркетингу, інноваційному маркетингу, соціально-етичному маркетингу, екологічному маркетингу, маркетингу 4.0, маркетингу стейкхолдерів та має на своїй меті забезпечення стійкого розвитку промислових підприємств - висококонкурентної позиції на ринку, капіталізації бренду за умови виробництва інноваційної продукції; досягнення максимального задоволення усіх стейкхолдеров: споживачів, осіб в організації, акціонерів, біз- нес-партнерів і суспільства за рахунок соціальної відповідальності у системі партнерських відносин, імплементації науково-технічних досягнень та впровадження сучасних технологій у ланцюжок створення споживчої цінності.

Нова ринкова модель економіки, орієнтована на споживача, поставила нові вимоги до одного з основних учасників ринку - промислового підприємства. На нашу думку промислове підприємство доцільно розглядати як елемент системи «споживач - підприємство - партнер». На основі літературного аналізу виявлено, що концепція маркетингу стійкості змінює традиційні цілі маркетингу - одержання максимального прибутку - на користь фрормування ефективних, взаємовигідних відносин 3 усіма учасниками ринкового середовища [14].

Висновки. Встановлено, що рівень розвитку суспільства вимагає розробки нової програми розвитку світової спільноти, що передбачає розробку інноваційних програм в усіх ссрерах, у тому числі у промисловій. Обгрунтовано, що стійкий розвиток, що не суперечить подальшому існуванню людства, ставить нові задачі перед маркетингом і об'єктивно обгрунтовує появу концепції гармонізації розвитку - маркетингу стійкості - нової фрілософрії бізнесу, що базується на: використанні принципів достатності, раціональності, блага, творчості і враховує не лише інтереси людини, але і усього людства і інтереси майбутніх поколінь; вихованні нового світогляду, заснованого на новій парадигмі; фрормуванні попиту на інновації, використання яких сприятиме розвитку нових взаємовідносин; застосуванні сучасних ефективних інструментів маркетингу, пов'язаних в єдину маркетингову систему. Запропоновано маркетинг стійкості промислових підприємств визначати, як стратегічну концепцію бізнесу, що грунтується на холістичній концепції маркетингу.

\section{СПИСОК ВИКОРИСТАНИХ ДЖЕРЕЛ:}

1. Могилевська О.Ю. Система ефективного розвитку сучасного промислового підприємства. Інвестиції: практика та досвід. 2011. № 23. С. 78-80.

2. Багиев Г.Л., Черенков В.И., Черенкова Н.И. Маркетинг для реализации концепции устойчивого развития: сущность и терминологическая парадигма. Известия СПб ГУ. 2018. № 4. С. 139-153.

3. Дуброва О.С. Стратегічна стійкість підприємства: складові та напрями ії забезпечення. Вісник Хмельницького національного університету. 2010. Т. 1. № 1. С. 15-19.

4. Слободчикова О.А. Механізм забезпечення стратегічної стійкості підприємства гірнично-металургійного комплексу в умовах проведення реструктуризації. URL: http://soskin.info/ea/2012/7-8201216.html (дата звернення: 08.12.2021).

5. Харазішвілі Ю.М. Системна безпека сталого розвитку: інструментарій оцінки, резерви та стратегічні сценарії реалізації : монограсія; Нац. акад. наук України, Ін-т економіки пром-сті. Київ, 2019. 304 с.

6. Устойчивый маркетинг: теория и практика устойчивого потребления / О.У. Юлдашева и др. Санкт-Петербург : Изд-во СПб гЭУ, 2017. 113 с. 
7. Belz F.-M., Peattie K. Sustainability marketing - An innovative conception of marketing. Marketing Review St Gallen. 2009.

8. Окландер Т.О. Трансфрормація концепції маркетингу в XXI сторіччі. Бізнес Інфрорм. 2011. № 7(1). С. $134-136$.

9. Акулова И.А. Оценка лояльности потребителей в системе маркетинга партнерских отношений. Бизнесинформ. 2006. № 6. С. 134-138.

10. Котлер Ф., Картаджайя Х., Сетиван А. Маркетинг 3.0. От продуктов к потребителям и далее - к человеческой душе. Санкт-Петербург : Эксмо, 2011. 240 с.

11. Котлер Ф., Сетиван А., Картаджайя Х. Маркетинг 4.0. Разворот от традиционного к цифровому. Технологии продвижения в интернете. Форс. 2019. 224 с.

12. Weber J., Lawrence A.N. Business and Society: Stakeholders, Ethics, Public Policy, 2013.

13. Bosch-Sijtsema P., Bosch J. User Involvement throughout the Innovation Process in High-Tech Industries. 2014. DOI: https://doi.org/10.1111/jpim.12233

14. Mohylevskaya O.Yu. A competitiveness of an industrial enterprise in the system of partner relations loyalty. Austrian Journal of Humanities and Social Sciences, «East West» Association for Advanced Studies and Higher Education GmbH. Vienna, 2017. № 3-4 (2). P. 122-128. DOI: http://dx.doi.org/10.20534/AJH-17-3.4-122-128

\section{REFERENCES:}

1. Mohylevska O.lu. (2011) Systema efektyvnoho rozvytku suchasnoho promyslovoho pidpryiemstva [The system of effective development of a modern industrial enterprise]. Investytsii: praktyka ta dosvid, no. 23. pp. 78-80. (in Ukrainian)

2. Bahyev H.L., Cherenkov V.Y., Cherenkova N.Y. (2018) Marketynh dlia realyzatsyy kontseptsyy ustoichyvoho razvytyia: sushchnost y termynolohycheskaia paradyhma [Marketing for realization the conception of sustainable development: essence and terminological paradigm]. Yzvestyia SPb HU, no. 4, pp. 139-153. (in Russian)

3. Dubrova O.S. (2010) Stratehichna stiikist pidpryiemstva: skladovi ta napriamy yii zabezpechennia [Strategic sustainability of the enterprise: components and directions of its provision]. Visnyk Khmelnytskoho natsionalnoho universytetu, vol. 1, no. 1, pp. 15-19. (in Ukrainian)

4. Slobodchykova O.A. Mekhanizm zabezpechennia stratehichnoi stiikosti pidpryiemstva hirnychno-metalurhiinoho kompleksu $v$ umovakh provedennia restrukturyzatsii [The mechanism for ensuring the strategic sustainability of the enterprise of the mining and metallurgical complex in the conditions of restructuring]. Retrieved from: http://soskin.info/ea/2012/7-8201216.html (accessed 08 December 2021). (in Ukrainian)

5. Kharazishvili Yu.M. (2019) Systemna bezpeka staloho rozvytku: instrumentarii otsinky, rezervy ta stratehichni stsenarii realizatsii: monohrafiia [System safety sustainable development: evaluation toolkit, reserves and strategic implementation scenarios: monograph]. Nats. akad. nauk Ukrainy, In-t ekonomiky prom-sti. Kyiv, 304 p. (in Ukrainian)

6. Ustoichyvyi marketynh: teoryia y praktyka ustoichyvoho potreblenyia [Sustainable marketing: theory and practice of sustainable consumption] / O.U. Yuldasheva y dr. (2017). Sankt-Peterburh: Yzd-vo SPb HEU, 113 p. (in Russian)

7. Belz F.-M., Peattie K. (2009) Sustainability marketing - An innovative conception of marketing. Marketing Review St Gallen.

8. Oklander T.O. (2011) Transformatsiia kontseptsii marketynhu v XXI storichchi [Transformation of marketing concept in the XXI century]. Biznes Inform. Kharkiv, no. 7(1), pp. 134-136. (in Ukrainian)

9. Akulova Y.A. (2006) Otsenka loialnosty potrebytelei v systeme marketynha partnerskykh otnoshenyi [An estimation the loyalty of consumers in the system of partner relations marketing]. Byznes-ynform, no. 6, pp. 134-138. (in Russian)

10. Kotler F., Kartadzhaiia Kh., Setyvan A. (2011) Marketynh 3.0. Ot produktov k potrebyteliam y dalee $\mathrm{k}$ chelovecheskoi dushe [Marketing 3.0. From products to the consumers and further - to the human soul]. SanktPeterburh: Eksmo, 240 p. (in Russian)

11. Kotler F., Setyvan A., Kartadzhaiia Kh. (2019) Marketynh 4.0. Razvorot ot tradytsyonnoho k tsyfrovomu. Tekhnolohyy prodvyzhenyia v ynternete [Marketing 4.0. Turn from traditional to digital. Technologies of advancement in the internet]. Fors, 224 p. (in Russian)

12. Weber J., Lawrence A.N. (2013) Business and Society: Stakeholders, Ethics, Public Policy.

13. Bosch-Sijtsema P., Bosch J. (2014) User Involvement throughout the Innovation Process in High-Tech Industries. DOI: https://doi.org/10.1111/jpim.12233

14. Mohylevskaya O.Yu. (2017) A competitiveness of an industrial enterprise in the system of partner relations loyalty. Austrian Journal of Humanities and Social Sciences, «East West» Association for Advanced Studies and Higher Education GmbH. Vienna, no. 3-4 (2), pp. 122-128. DOI: http://dx.doi.org/10.20534/AJH-17-3.4-122-128 